\title{
National port development policies: same problems, different solutions?
}

\author{
Cassia Bomer Galvao (PUC/SP) - cassiabgalvao@gmail.com \\ Alessio Tei (Newcastle University) - Alessio.Tei@newcastle.ac.uk \\ Sophia Everett (Victoria University) - Sophia.Everett@vu.edu.au \\ Leo Tadeu Robles (UFMA) - leotadeurobles@uol.com.br
}

Claudio Ferrari (Università degli studi di Genova) - ferrari@economia.unige.it

Luciana Guerise (Associação dos Terminais Portuários Privados) - lguerise@gmail.com

Ross Robinson (Victoria University) - Ross.Robinson@vu.edu.au

\begin{abstract}
National governments in different trade and shipping environments often face a number of common critical issues in port systems but government policies, processes and associated regulation may differ significantly. Why is it so? Ports are essential elements in trade oriented supply chains and during the past thirty years have undergone widespread reform globally. This has resulted in a deregulated market generally associated with denationalisation, privatisation or corporatisation programs, which aimed, inter alia, to increase efficiency; to attract additional investments, from the private sector; and to smooth land/port interfaces developing integrated supply chains. The port reform issue has attracted significant research globally with a focus generally on particular countries or regions. There has been less emphasis comparing countries in different contexts. This paper seeks to fill this gap and compares the main features of reform, government policy and regulation in three national jurisdictions: Australia, Brazil and Italy. It highlights differences, similarities and common aspects: full or partial privatisation, the landlord port model and regulatory regimes enacted. It examines the degree of private sector involvement; government intermediation roles and regulation in an increasingly deregulated market. It concludes that port privatisation policy remains, regrettably but not surprisingly, an intensively divisive and deeply political and politicised issue.
\end{abstract}

KEYWORDS: Port reform; public policy; regulation; deregulation; supply chain integration.

\section{RESUMO:}

Os governos nacionais em diferentes contextos comerciais e marítimos muitas vezes enfrentam uma série de questões críticas comuns aos sistemas portuários, mas as políticas governamentais, os processos e a regulamentação associadas podem diferir significativamente. Por que isto ocorre? Os portos são elementos essenciais nas cadeias de abastecimento orientadas para o comércio e, nos últimos trinta anos, foram submetidos a uma ampla reforma global. Isso resultou em um mercado desregulamentado geralmente associado a programas de desnacionalização, privatização ou corporativização que visavam, entre outros objetivos, aumentar a eficiência; atrair investimentos adicionais do setor privado; e para facilitar as interfaces terra / porto, desenvolvendo cadeias de suprimentos integradas. A questão da reforma portuária atraiu pesquisas importantes em todo o mundo com foco em países ou regiões particulares, no entanto, houve menos ênfase na comparação de países em diferentes contextos. Este artigo procura preencher essa lacuna e compara as principais características da reforma, da política governamental e regulação em três jurisdições nacionais: Austrália, Brasil e Itália. Destaca as diferenças, semelhanças e aspectos comuns: a privatização total ou parcial, o modelo landlord e os regimes regulatórios promulgados. Examina ainda o grau de envolvimento do setor privado; os papéis de intermediação do governo e regulação em um mercado cada vez mais desregulado. Conclui que a política de privatização dos portos permanece, lamentável, mas não surpreendentemente, uma questão intensamente divisória e profundamente política e politizada.

PALAVRAS-CHAVE: reforma portuária; políticas públicas; regulamento; desregulamentação; integração da cadeia de abastecimento.

\section{Universidade Fluminense}

R. Desembargador Ellis Hermydio Figueira, 783, Bloco A, sl. 218, Aterrado. 27213-415 - Volta Redonda, RJ - Brasil www.uff.br

Copyright (C) 2017 RASI. Todos os direitos, até mesmo de tradução, são reservados. É permitido citar parte de artigos sem autorização prévia, desde que seja identificada a fonte 


\section{National port development policies: same problems, different solutions?}

Over recent decades, governments in most western democracies have faced similar problems in their port systems though solutions sought and implemented have differed significantly. In many instances ports and government, enterprises generally have transited from a traditional public utility model to a largely deregulated market associated with policies of denationalisation and deregulation with the objective of increasing efficiency, reducing the financial burden and attracting additional, alternate sources of investment, particularly from the private sector.

Ports and port authorities, within this context, have been required to meet both the changing demands of governments as well as their customers. Ports exist to serve trade and their services are demand driven and in the last decades have been required to adapt to technological and commercial changes including size and types of ships; growth in trade and trade patterns; efficiency and investment policy. These developments have had a significant impact on port expansion and investment - on draught, types and lengths of berths and on labour requirements. In addition, the rapid growth in trade and the emergence of newly developing economies in Asia introduced changes in traditional trade patterns and, together with the increasing vessel size, saw the development of hub ports and feeder services. This led to changes in port sizes and locations - the development of a select few larger hub ports and a plethora of smaller feeder ports. In addition to trade growth, demands for different types of cargo also occurred - the oil shocks of the 1970s saw the growth in the global demand for thermal coal and the growing global demand for steel production in developing economies saw a rapid demand for iron ore, particularly from Australia and Brazil, as well as metallurgical coal. These developments impacted further on the types, size and locations of ports as well as investment policies and ownership. Governments under pressure associated with recessions of the 1970s responded initially by imposing a commercial charter on public utilities, such as ports and railways, endeavouring to transform them from a public utility model to commercially oriented businesses. The philosophical and ideological changes occurring at this time are significant constituting a paradigm shift (Kuhn 1970). Global recessions in the 1970s and 1980s had led to questioning whether the Keynesian model associated with widespread public sector growth and state expansion, remained appropriate. The high cost of the expanding public sector, emerging stagflation in the 1970s exacerbated by a series of oil shocks were drivers of economic crises globally. A new orthodoxy subsequently emerged based on a revival of classical ideals of liberalism and theories of neoclassical economics. This paradigmatic change called for a reduction in government spending, the shrinking of the public sector and the deregulation of government-owned businesses.

The impact on the port sector, in many instances, led to a largely deregulated market with governments adopting privatisation and corporations programs with the objective of reversing the drain on the public purse, enhancing efficiency and the creation of a competitive market with government withdrawal as monopoly providers of commercial services.

The paper explores, in particular, the ongoing roles of governments in the port sectors operating in significantly different contexts and jurisdictions. Is government's role that of a landlord? A regulator? A port planner? A policy maker? And what are the impacts of these on port and supply chain structures. We are using a case study methodology to compare the three countries and to highlight the main differences, similarities and anomalies. Following this introduction section 2 presents the methodology and a select literature review; section 3 focuses on the port reform context; section 4 presents three case studies (Australia, Brazil and 
Italy); section 5 discusses the main differences, similarities and anomalies and section 6 provides some concluding comments and insights for future research.

\section{Select literature review and methodology}

Research into the port reform phenomenon has attracted attention globally but has tended to focus on particular jurisdictions and issues. Earlier research pointed to the widely adopted landlord port model in western economies (Goss, 1990 and 1997; Baird and Valentine, 2007; Everett and Robinson, 2007; Parola et al., 2012) which was subsequently emulated in emerging economies (Galvão et al., 2013 and Wang et al., 2004). This constituted the beginning of privatisation as port authorities became landlords and responsibilities for commercial operations were transferred to the private sector. Under this model the port remained government owned generally headed by a port authority responsible for coordination and planning (Goss, 1990) although Parola et al. (2012) indicate that, in many instances, they also retained regulatory and coordinating functions. Robinson (2002) has argued, furthermore, that the role of the port during this period was better conceptualised as an element embedded in complex supply chains articulating flows between sellers and buyers and delivering and capturing value in so doing rather than as simply a place in which cargo was handled - either efficiently or inefficiently. While research into port reform has been widespread there has been little attempt at comparative studies. A compendium of case studies compiled some years back (Brooks and Cullinane 2007) provided a description of reform in a number of different countries but with few exceptions (Chen and Everett 2014) there was little attempt at comparative studies in different jurisdictions. Cariou et al. (2014) point to a strong central government focus in France while Everett and Robinson (2007) indicate state government jurisdiction in Australia. Galvão et al. (2013), on the other hand, point to a multi-jurisdictional model in Brazil with federal, state and regional government involvement.

More significantly there has been little attempt to include a discussion in much of this research into policy-making processes - that inherently political activity that determines how and why a particular strategy was arrived at. An important focus of this paper, therefore, is not only on port reform per se but on government policy and processes - on how governments faced with similar problems implemented significantly different solutions. This paper has a particular focus on the processes of policy-making and on the relationship between process and outcome - on how governments make policy and what are the key drivers on policymaking. This is an issue little appreciated in the economic literature where much of the discussion centres on the content of policy rather than on why and how a particular policy was adopted.

In an era in which much research seeks to emulate the scientific model - a methodological approach based on facts established by repetition, observation and experimentation and generally expressed in quantitative terms (Chalmers, 1999) - how do we analyse political events which generally appear discrete or which occur on an ad hoc basis? Are these events amenable to analysis? Power relations and politics are not readily amenable to 'scientific' analysis but are nevertheless explicable requiring a different set of tools. Skidelsky (2010) indeed, highlights some methodological flaws in the recent macroeconomic analysis of 'depression economics' when applying a strictly quantitative approach and relying on a discipline which focuses increasingly on the production of economic models which may have little relation to reality and where 'real world' findings are increasingly disguised 'by sophisticated mathematics and statistics'. This is not to assert that economic models are not 
important tools in scientific discovery; they are, but only to the extent that they are real-world relevant. A framework, which focuses exclusively on quantitative input ignoring 'real world' qualitative data, is seriously flawed and certainly incomplete.

The focus of this paper is the manner in which governments, faced with similar problems, enacted policies that led to significantly different outcomes. Initial research will consist of a highly focused literature review including legislation enacted during the research period, government reports as well as other relevant publications. This paper seeks to fill this gap comparing the main features of reform in three national jurisdictions - Australia, Brazil and Italy - highlighting differences and similarities. We understand that the case study is the appropriate methodological approach for the following reasons - current issues are ongoing and not entirely resolved; the phenomenon itself is complex and requires a multidisciplinary approach and there are multiple sources involved to understand the ongoing decision process. (Yin, 2003).

\section{The Context of change}

Port reform from the late 1970s onwards, as noted above, constituted a paradigm shift (Kuhn, 1970) from a traditional public utility to a free market model. These changes did not occur on an ad hoc basis or, as noted above, emerge in a vacuum - there were significant political/ideological and economic drivers (Macfarlane, 2006). The transition from what is frequently referred to as the Golden Age (1945 to 1973) to the beginning of reform was associated with the liberalisation of trade and changes in government policy from Keynesianism to neo-classical economics and free market paradigms. Macfarlane cites a number of reasons for this transition - post World War II reconstruction, for example, which was associated with policies of nationalisation, state expansion and growth of the government sector. Furthermore, he points to the impact of the subsequent liberalisation of international trade associated with the reductions in tariffs and quotas and, as a result, trade flourished and imports and exports grew leading to the growth and expansion of port and other transport infrastructure undertaken by governments.

Maddison (1991) suggests that while the Golden Age was associated with a remarkable revival of liberalism in international trade, by the late 1960s and certainly by the early 1970s, this was coming to an end and intellectual ideas were shifting. While macroeconomics in the 1960s was dominated by the Keynesian vision of government expenditure as a necessary lubricant to ensure that the economy operated at full employment, the high inflation and low growth period of the 1970s burst the Keynesian bubble (King and Maddock, 1996).

In addition, a number of oil shocks $(1973,1979$ and 1981) and stagflation saw widespread recessions globally lasting for a decade or more. Within this context, the high cost of a large scale government sector was no longer affordable leading to demands for smaller governments and the shrinkage of the public sector. In the United Kingdom (UK), in particular, in reaction to the earlier nationalisation strategies of the 1940s which had led to the rapid growth of the government sector, a winding back was called for. Questions were raised about the role of government; what should be controlled by the state and how much should be left to the forces of the free market and the private sector (Beresford, 2000).

Although widespread earlier agreement had promoted an interventionist form of government, these ideals were undermined a decade later by advocates of smaller government and private enterprise. Subsequently, the new orthodoxy that emerged, initially in the United 
States of America (USA) and UK, but was rapidly adopted in other western economies, sought to create a more competitive and efficient market and to shrink the public sector reducing the fiscal burden on governments (Quiggin, 1996). A massive reform program ensued initially in the USA beginning with the deregulation of the airline industry in 1978 while in the UK the Thatcher government began by selling off public utilities such as British Telecom. Elsewhere the reform and privatisation of railways and sea and airports followed.

Reform models varied significantly but ports, in most instances, remained publicly owned although from the 1970s onwards terminals were increasingly leased to the private sector. By the 1990s, however, the landlord model was widespread in developed economies and privately owned ports were gaining momentum.

Baird and Valentine (2007) identified two distinct phases of the sale of state-owned ports in the UK. The first involved the sale of state-owned ports in the 1980s and phase 2 saw the disposal of major trust ports. In the USA ports were for the most part publicly owned, governed by public boards and frequently operated by tenants or lessees of those agencies (Fawcet, 2007). And in the port of Singapore the jurisdiction of cargo operations and port regulation up to 1996 were the jurisdiction of three government agencies, but following the enactment of the MPA Act 1996 the port authority, while retaining responsibility for the regulation of essential port and marine services, relinquished control of most operational aspects of the terminal businesses (Cullinane et al., 2007). In a context of global trade, ports play a crucial role and the experiences of ports in Australia, Brazil and Italy are analysed in this paper.

\section{The three case studies: Australia, Brazil and Italy}

\subsection{The Australian Case}

Port reform in Australia has been underway since the 1980s driven initially by efficiency objectives and transforming ports into economically viable businesses. The mechanism for this has been by deregulating the port sector and exposing it to the forces of the market by way of commercialisation, corporatisation and privatisation strategies. Unlike many other countries, Australian ports are the jurisdiction of state and territory governments and, consequently, different ownership models are in place as each jurisdiction enacted statebased legislation. This is a vestige of history as ports were initially established by colonial and later state governments and, following Federation in 1901 and the adoption of the Australian Constitution, the responsibility remained vested with state and territory governments.

An endeavour to transform ports into commercially oriented businesses has been underway for much of the $20^{\text {th }}$ Century initially by adopting the statutory authority model. This was an endeavour to minimise direct government and political control although, in accordance with the Westminster system of government, accountability remained through the relevant Minister to the parliament. Since the 1980s, port reform has been ongoing but can be divided into two main periods. The first, from the mid-1980s up to 2000, dealt with deregulation, the enactment of National Competition Policy and was associated with corporatisation and privatisation strategies driven by a drastic need to address extraordinary inefficiencies in port operations. This phase has been dealt with extensively elsewhere (Everett and Robinson, 2007; Everett and Pettitt, 2006) and will not be duplicated here. The second phase - the focus of this case study - has not been driven by efficiency issues per se but is characterised by the ownership and expansion of bulk ports and is associated with 
overseas investment in the mining sector; the sale of capital city ports and, most recently the development of initiatives to achieve integrated, end-to-end supply chains.

Expansion of bulk exports: The resources boom has seen Australia emerge as the world's largest coal exporter. Growth in global steel production led to an increase in metallurgical coal exports from 273 million tonnes (mt) in 2010 and is projected to reach $464 \mathrm{mt}$ by 2020 . Similarly, thermal coal exports are projected to exceed 390mt in 2015 (AGPS, 2010). This increase has been associated with significant expansion and growth in coal export facilities in some cases doubling throughput capacity. It is anticipated that Queensland's coal port capacity will reach $787 \mathrm{mt}$ by 2020 (AGPS, 2010). Projected expansion of thermal coal exports, similarly, is driven by overseas demand, particularly from China and India importing 16 and $13 \%$ respectively of total thermal coal exports and is projected to increase to $18.5 \%$ each by 2025 (ABARE 2010). These countries have invested heavily in Australia's coal and iron ore sectors forming part of fully integrated supply chains. Adani Holdings ${ }^{1}$, for example, acquired the Abbot Point Coal Terminal in 2011; has a mining lease in the Queensland's Galilee Basin and is projected to export $60 \mathrm{mt}$ by 2020 ; is building a railway line to the company's dedicated terminals where the coal is loaded onto the company's bulk fleet destined for India providing fuel for the company's power stations (Everett and Robinson, 2012) (Figure 1).

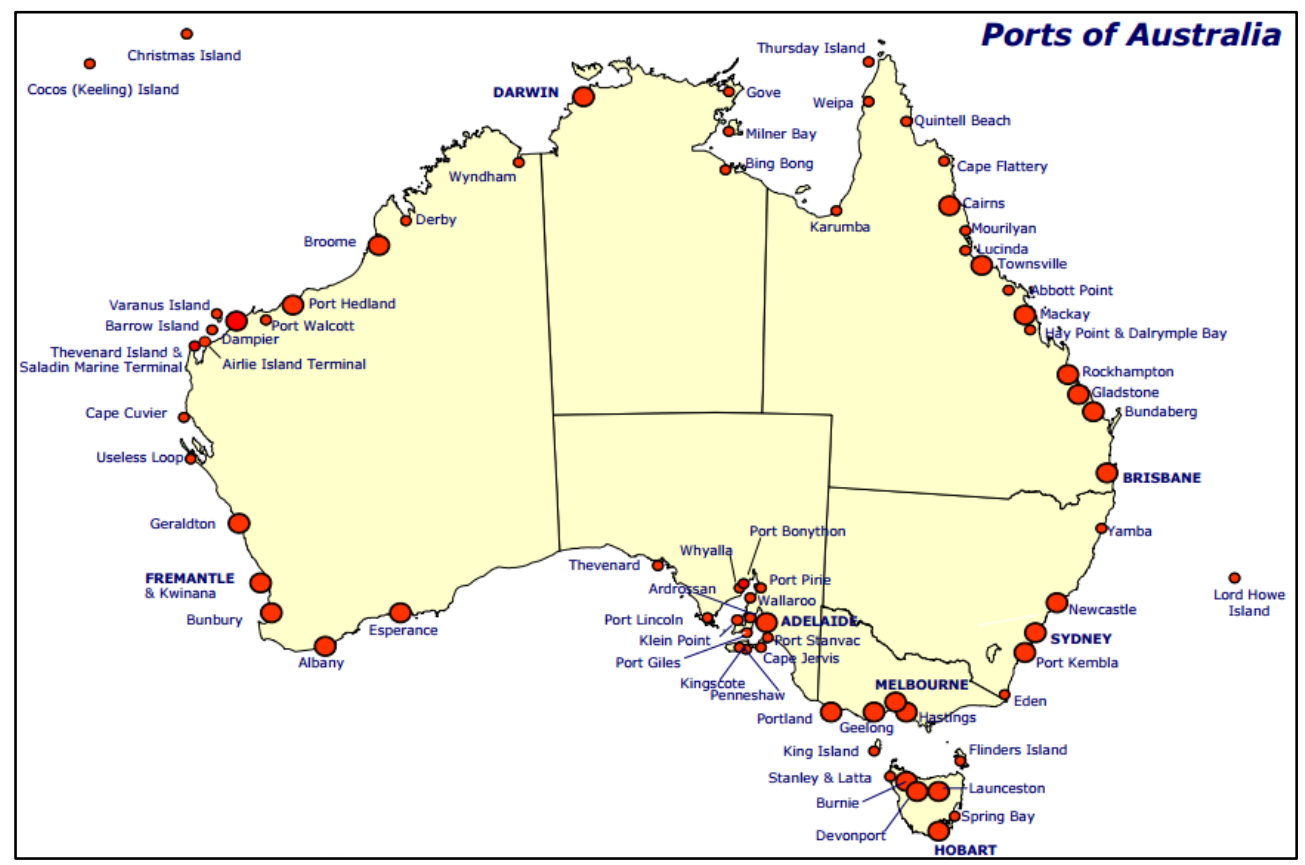

Figure 1. Australian port system. Source: Ports of Australia, 2015.

Chinese interests have also invested heavily in the mining sector. Yancoal Australia, for example, exports both thermal and metallurgical from Queensland and New South Wales (NSW) to China. The majority shareholder (78\% equity) of this development is Yanzhou

\footnotetext{
${ }^{1}$ The Adani Group acquired Mundra Port Pty Ltd - is India's largest private multi-port operator and integrated infrastructure corporation
} 
Coal, formed in 2004 and consists of Chinese interests securing future sustainable supply. Yancoal Australia has also invested in export infrastructure. In the Port of Newcastle, for example, a third terminal, National Coal Infrastructure Group (NCIG) was commissioned with a 66mt capacity bringing the total annual capacity in that port to $212 \mathrm{mt}$ with Yancoal Australia as a majority shareholder (Newcastle Port Corporation, Annual Report, 2013). In addition, the Port of Newcastle was sold by the NSW state government in 2013 for $\$ 1.75 \mathrm{~b}$ to a consortium which includes China Merchants Group - a state owned corporation of the People's Republic of China involved in port operations and bulk cargo transportation. Chinese interests have also invested in Australia's iron ore sector - the Chinese state-owned Baosteel, for example, acquired Aquila Resources in 2014 (Business Spectator, 2014) and the company is in the process of developing new iron ore mines as well as rail and port infrastructure in the Pilbara region of Western Australia (Reuters, 2014). Note that iron ore exports from Western Australia totalled 556mt in 2013 of which 418mt (75\%) was destined for China according to Government of Western Australia Department of Mines and Petroleum (2014).

Sale of capital city ports: The latest reform has also led to the privatisation of some capital city ports. The government of Queensland, for example, following the enactment of the Infrastructure Investment (Asset Restructuring and Disposal) Act 2009 privatised the Port of Brisbane for $\$ 2.1 \mathrm{~b}$ - part of a $\$ 15 \mathrm{~b}$ privatisation program; and the state government of NSW, following the enactment of the Ports Assets (Authorised Transactions) Act 2012 finalised a 99 year lease for the transfer to the private sector of Port Botany and Port Kembla for $\$ 5.07 \mathrm{~b}$. The yield of this sale is destined to be invested into motorway and urban transport projects. In the State of Victoria bilateral agreement was reached in May 2014 between the major political parties that the Port of Melbourne would be privatised by way of a 40 year lease. This venture is not complete but the projected revenue raised is estimated to be in the vicinity of $\$ 5 \mathrm{~b}$ and is expected to be used for major road and rail projects.

The rationale for this latest spate of selloffs differs from the earlier privatisation projects. The sale of Geelong, Portland and the South Australian ports, as noted above, was driven by efficiency objectives and were acquired by Australian interests. The Port of Geelong, for example, was sold to TNT in 1996, and subsequently acquired by Toll Holdings in $1998^{2}$ - Australia's largest logistics and supply chain operator seeking integrated chain control from producer to consumer. The more recent sale of the capital city ports of Brisbane and Sydney's Port Botany were revenue raising exercises providing funding for land based transport infrastructure as well as reducing government debt.

Deregulation and the development of end-to-end supply chains: Recent reform and government policy of deregulation has dramatically changed the face of transport in Australia and has been a necessary condition for the development of integrated supply chains. Deregulation, in this sense, has a specific meaning. On the one hand, and in its strictest sense, it describes a process of removing or reducing state regulation. This definition is not appropriate for Australia has not adopted a laissez-faire model. Indeed, the process has been one of re-regulation in which one regulatory regime has simply been replaced with another. Ports are now subject to the provisions of a Commonwealth regime, the Australian Competition and Consumer Commission Act 2010 as well as relevant state based regulatory regimes, in Victoria, for example, the Essential Services Commission Act 2001. On the other hand, deregulation has another meaning, which applies particularly to the Australian reform

${ }^{2}$ Toll merged with Patricks in 2007 became part of the Asciano company. 
process and constitutes a removal of government monopoly control. Deregulation in this sense follows the enactment of National Competition Policy in 1995 with the aim of promoting microeconomic reform. An essential feature of this was enhancing productivity and efficiency with the abolition of government monopoly control and the introduction of competition in the market. This was a fundamental enabler of the development of integrated and efficient supply chains and has led to the extensive restructuring of freight markets and more particularly port-linked markets (Robinson, 2009). It has also been symptomatic of an underlying paradigm shift, as noted above, with the conceptualisation of ports not simply as places handling ships and cargo but as critical functional elements in chain and supply chain systems (Robinson, 2009). In short, the planning and development challenge is to optimise whole-of-chain port-dependent systems - not simply to make individual ports more 'efficient' (Robinson, 2002).

In Australia, this shift has been slow - and not necessarily self-evident or tightly managed. In 2002, the growing concern about the parlous state of the pan-Australian transport, logistics, freight and shipping networks prompted 'A Freight Transport Industry Action Agenda' (DOTARS, 2002). In 2004, a 'white paper' (the so-called AUSLINK White Paper) (DOTARS, 2004) focused, significantly, on a national framework for integrated transport planning and infrastructure development. This was an important step ahead - but four years later, in 2008, a new position paper from the Australian Logistics Council - The National Strategy for the Transport and Logistics and Freight Industry: Enhancing Australia's Supply Chains (ALC, 2008) overtly recognised infrastructure development as a key to more efficient chains - in effect as a derived demand (Robinson, 2015). By 2010, Federal authorities had tabled a national ports strategy (Infrastructure Australia and NTC 2010) and a national land freight strategy (Infrastructure Australia 2010) respectively; but as important as a national, pan-Australian perspective is, it is clear that the Australian States - which have constitutional jurisdiction over ports - will not cede this status to the Commonwealth. A change of government in 2013 has led to a further spate of policy changes not yet implemented by the incumbent.

\subsection{The Brazilian Case}

Since June $5^{\text {th }}$, 2013 Brazilian ports have been subject to the provisions of Law N. 12815, which replaced the 1993 Law 8630. Under present legislation, ports as institutional structures are subject to the Port Secretariat (SEP), established in 2007 with ministerial status and linked directly to the Presidency ${ }^{3}$ and the National Agency for Waterways Regulation (ANTAQ), created in 2001, as the regulatory agency. The Law 12815 was approved by the Brazilian Congress and submitted to the Presidency for final approval - thirteen points were vetoed, however. Despite the Law's validity, it has been returned to the Congress to be passed but at present the matter is still pending.

The Brazilian port structure is characterized by private operations in Public Ports (PP) and in Terminals for Private Use (TUP). Land in the PPs are publicly owned and managed by ANTAQ and SEP. ANTAQ (2015) records show a total of 34 commercial public ports in Brazil, 21 of these are managed by federal government enterprises (previously known as "Dock Companies"); 13 are the jurisdiction of state governments and two are structured as municipal companies (Figure 2). At present there are 92 TUPs (ANTAQ's Resolution N.

\footnotetext{
${ }^{3}$ Previously, the ports sector was linked to the Ministry of Transport, as a general agency responsible for the planning and regulation of Transports in Brazil. The SEP was established in order to develop the port sector in particular.
} 
2969 from July, 2013), which are owned by the private companies approved by ANTAQ. Under Brazil's structure, the PPs are managed by Port Authorities (PA), which have advisory boards frequently appointed for political purposes. In addition, PPs have a Council of Port Authorities (CAP) - which consists of public and private users and operators as well as trade union representatives. Furthermore, there is the Labour Management Body - OGMO representing independent workers (dockers) and operators with the responsibility for hiring the labour force.

Port operations in PPs are conceded to private companies by way of leasing agreements following a bidding process. Leasing agreements conceded to private companies participating in this process are for specific cargo types in a determined area of the port consistent with the port development and zoning plan (PDZ). The obligation and compulsory use of OGMO workers at the public ports is presently under discussion and is associated with political and social implications. The OGMO was enacted by Law 8630/1993 in order to replace the role of docker unions in hiring independent workers (dockers) - a model still in place in many other ports globally. Although these unions continue to exist, their power and influence have diminished over time in part due to the reduction in membership numbers associated with containerization and modern, less labour intensive, cargo handling equipment.

Most private port operators, however, are relying on a permanent labour force in order to avoid the OGMO requirements. In the Brazilian system, TUPs have the freedom to do this. This matter continues to be a complex and controversial issue and discussions and associated conflicts persist in some ports. In the Port of Santos, the main Brazilian port, the new private container terminals such as Embraport and Brazil Terminal Portuario (BTP), 50\% labour requirements are filled with permanent workers as per an agreement with OGMO, while the Libra Terminal is legally operating with a $100 \%$ labour force of permanent workers.

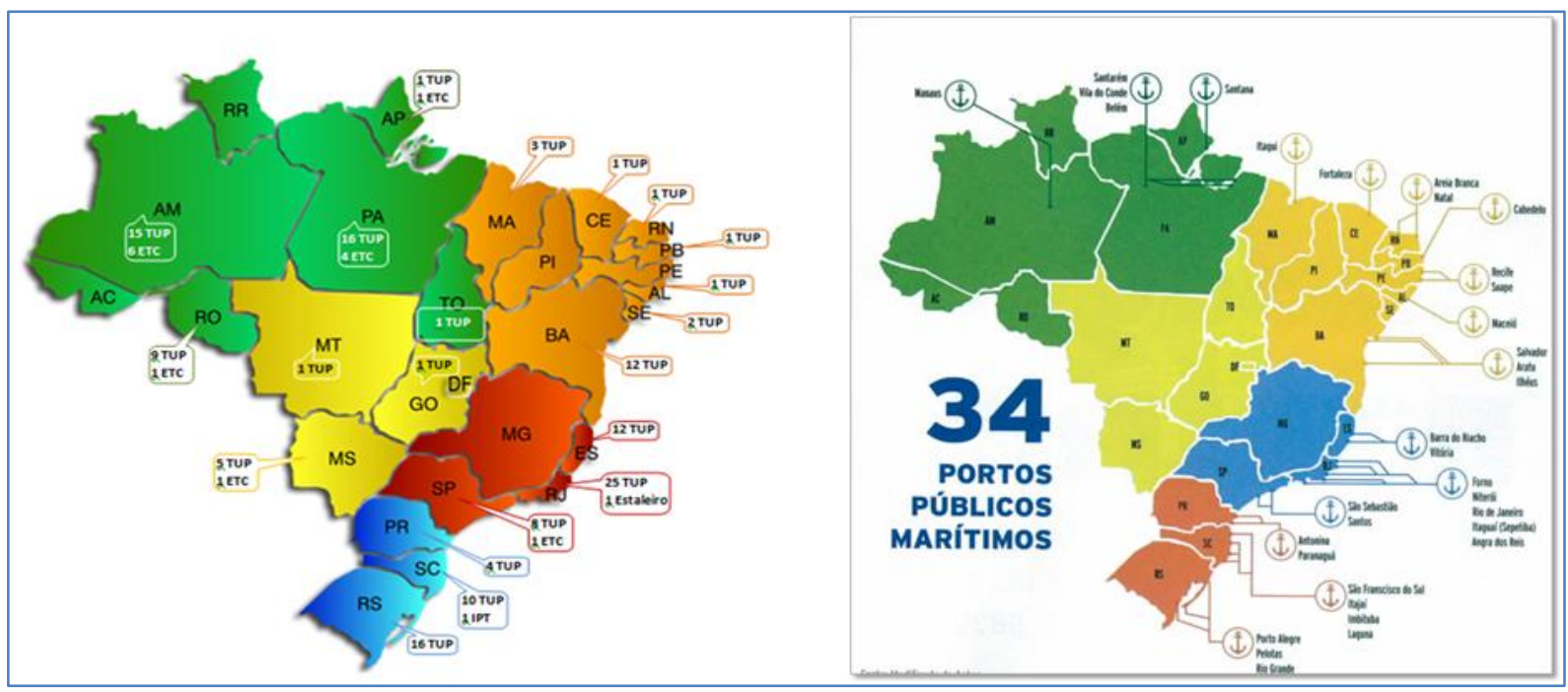

Figure 2. Brazilian port system

Source: ANTAQ (2014).

The Port Authorities operate under a landlord port model with the private sector operating under concession/renting contracts for a specific set of terminal activities such container, liquid bulk, general cargo, Ro-Ro, etc. and for a particular period of time, generally from 20 to 25 years. The contracts are controlled by ANTAQ and usually specify the investment requirements - from both the public and the private sectors - as well as the 
projected operational performance. The TUPs, as single terminal structures, are usually dedicated to a single cargo type and linked to industry supply chains - moving oil on behalf of the Brazilian company (Petrobras) or dry bulk products, such as iron ore on behalf of VALE, the world's largest iron ore company, using company owned dedicated export facilities. The growth rate of the PPs in the 1990 to 2013 period exceeded that of the TUPs primarily due to the growing number of containers moved by private operators in PPs. For example, in the year 2013, from a total of $931 \mathrm{mt}$ of cargo moved in Brazil 593mt (or 63.7\%) was handled by TUPs. (ANTAQ, 2013).

A large number of existing concession contracts ${ }^{4}$ have either ended or are due to end in the near future and are due for renewal. At present a critical issue surrounds the bidding process, as per Law 12815/2013 which has not yet been fully operationalized. The emerging concession deadlines have created a precarious situation particularly in relation to either slowing down or delaying investments. Industry representatives have indicated that a potential investment exceeding US $\$ 55$ billion has, as yet, not been allocated as a result. For example, since the Law 12815 was approved in 2013, SEP has planned to bid for terminals in the Port of Santos and the Port of Belem ${ }^{5}$, but to date the Federal Account Audit Court of Brazil $\left(\mathrm{TCU}^{6}\right)$ has not finalised its bidding process.

Like elsewhere in the world there have occurred significant changes in infrastructure ownership in Brazil. In the initial phase of Brazilian port privatization, the investors were predominantly Brazilian firms ${ }^{7}$. In recent times, however, Brazil has experienced an inflow of foreign investment from leading global operators such as Dubai Ports and APMT. In some cases, these major stevedoring operators have formed joint ventures with container shipping lines ${ }^{8}$ in an endeavour to form integrated chains.

Despite delays in bureaucratic and political processes, it is clear that the ongoing role of the private sector in port operations will continue and has been enacted by legislation - that is Law 12815/2013. However, it is unclear how the concession process will accommodate present players and potential newcomers into the market in both PPs and TUPs. Despite some difficulties, the port reform process in Brazil has been successful as it has attracted significant investment in ports ${ }^{9}$ enabling modernization of terminal infrastructure, enhancing operational efficiency and reducing cargo handling costs which has benefited both operators and users alike. However, as the initial contracts are due to expire, new operators are entering the market and the Government is actively seeking to attract new investors. A number of questions remain unanswered, however. How will this process be undertaken? And what can be done to reconcile possible conflicts of interests? What direction will further reform take in

\footnotetext{
${ }^{4}$ There are, according to ANTAQ's data, 52 renting contracts dated from previously to 1993, which corresponded to 42 firms and some of them (47) are under temporary resolutions to get extension, five without resolution and 10 among them with legal procedures in action. After 1993, there are 43 contract for which it was requested their contract rebalancing with 28 have been evaluate by ANTAQ and eight under SEP analysis.

${ }^{5}$ Port of Santos is the main Brazilian port and it is located on Brazilian Southeast region and Port of Belem in northern Brazilian state of Para in the Amazon region.

${ }^{6} \mathrm{TCU}$ is a public entity responsible in charge of analysing and evaluating government initiatives and accounts.

${ }^{7}$ The main Brazilian groups operating containers terminal are Santos Brasil, Libra Terminais and Rodrimar which operate in Port of Santos and other terminals all over the country.

${ }^{8}$ At the Port of Santos, the two most recent private investments are referred to: BTP (a partnership of MSC and Maersk) and Embraport (a partnership with DP World). In Port of Itajai (Santa Catarina (SC) state in South of Brazil) there are: Portonave (which has MSC participation) and Teconvi (as part of Maersk Group) and Port of Itapoa (SC) terminal has participation of Hamburg Süd. Another case is Port Central in Espirito Santos (ES) state (Southeast region) with the participation of Port of Rotterdan.

${ }^{9}$ Galvão et al. (2013) showed that the total investment in ports jumped from US\$ 100 billion in 1999 to US\$ 700 billion in 2008 and cargo movement from 400mt to almost $900 \mathrm{mt}$.
} 
this institutional and political environment? Industry leaders such as ABTP (Brazilian Association of Port Terminals), Fiesp (Sao Paulo State Industry Federation) and Firjan (Rio de Janeiro State Industry Federation) have expressed concern associated with these uncertainties and bureaucratic delays in renewing or extending existing contracts and suggest they are the main reasons for industry delaying further private sector investments. These concerns were documented in Proposals for the port sector - a report distributed to the three Presidency candidates during the 2014 election.

Other issues of concern are related to a) the enforcement of the Law 12815/2013 dealing with changes in PA and CAP roles and the centralized control at the federal government level; b) PA budgets being determined by the federal government and, as a result, the PAs have no financial autonomy for investment. This means that port investments require government assistance and authorization and is particularly critical for dredging programs, for example. A further general issue centres on the multi-jurisdictional regulatory environment involving a number of public bodies - customs for import/export flows, for example; the Sanity Authority (for the import/export of specific products; and the Navy Authority for safety and security issues. This multiplicity of responsibilities and functions tends to create delays in bureaucratic processes, impacting negatively on both ships and cargoes.

\subsection{The Italian case}

The total throughput of the Italian port system compared with other major ports is relatively modest. The 2012 Italian Association of Port Authorities ${ }^{10}$ (Assoporti, 2014) statistical report, for example, noted that the total throughput of the entire Italian port system was approximately $460 \mathrm{mt}$. In the same year the port of Rotterdam handled more or less the same tonnage while the throughput of the port of Antwerp - the second largest port in Europe - was comparable to the total tonnage of Italy's five largest ports.

Figure 3 illustrates the current Italian port situation in which 24 Port Authorities (PAs) were established by legislation under the port law (N.84/1994). These represent the main national gateways although the majority are only relatively small ports in terms of absolute values compared with Italy's main international competitors. Among the 24 ports only 4 exceeded 30mt throughput in 2012 and only 2 (Genoa and Trieste) have frequently handled more than $50 \mathrm{mt}$ in recent years. Moreover, several ports are highly specialized for some specific cargo types despite the fact that a relatively small number handle considerable throughput. Italian ports do have a significant passenger throughput, however, compared with main European competitors - in 2012 passenger transit accounted for almost 40 million passengers - in some cases this was due to some hub ports in the cruise market as well as ferry terminals associated with the island traffic.

The 24 main Italian ports are managed by a Port Authority (PA), a public regulatory authority with the responsibility for planning as well as port development but are not actively engaged in operational activities. The current port system derives from the reform law enacted in 1994. Prior to the 1994 reform, Italian ports were ruled by public entities entitled to directly operate inside and outside the port boundaries. At that time Italian ports resembled the typical "public port" model as depicted in the World Bank report (World Bank, 2001) in which ports

\footnotetext{
${ }^{10}$ In this contribution only national statistics have been used in order to guarantee the comparability of the values. Several national Port Authorities use different conversion rates among TEUs, tonnes and Ro-Ro vehicles and then only statistics from Assoporti or the National Statistical Institute (ISTAT) can be considered homogenous among the ports' publications. For this reason main statistics are based on the 2012 and 2013.
} 
were publicly managed with some private operators. Under that model all port infrastructure and services were provided by the public authorities.

Parola et al. (2012) argued that at the beginning of the 1990s the main ports had high debt levels, were inefficient with poor productivity levels - a product of labour force surplus. This gave rise to a new organisational model and significant investment in new terminals transforming a traditional labour intensive operation into a capital intensive activity in which productivity and terminal efficiency became the key issues to secure competitive advantage.

These critical issues coincided with the push by the European Union (EU) for Italian governments to increase competitiveness in the transport sector. Until 1994 competition between port services was not possible due to the chosen organizational model (Righetti, 1987). There was little financial input from the private sector at the time although some exemptions occurred in the biggest Italian ports, such as Genoa, in which specific agreements between the Port Government body and some private companies were established in order to expand the original port basin or to better connect industrial berths to the factories.

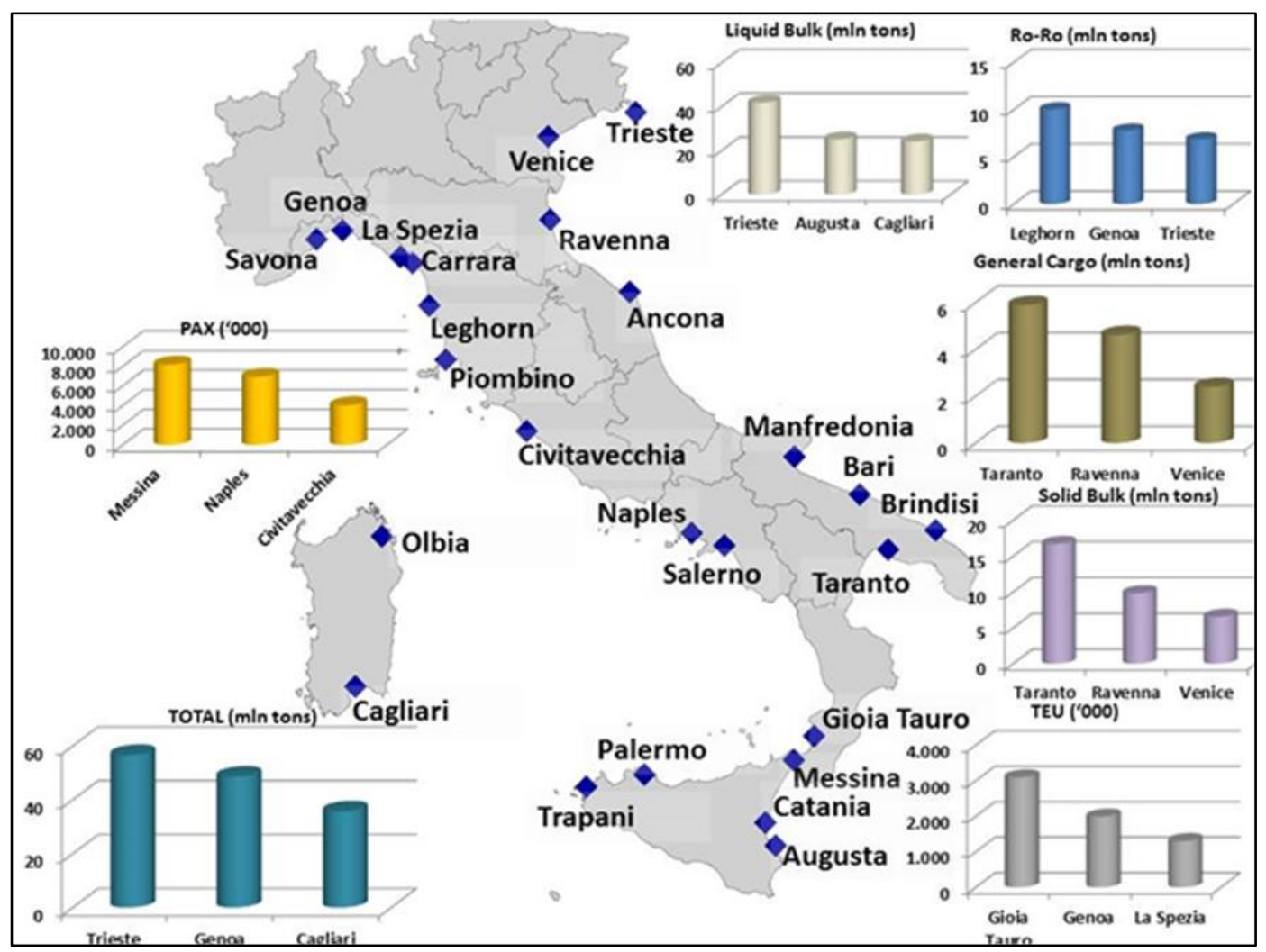

Figure 3. Italian port system

Source: Authors. Based on Assoporti data, 2014.

At the end of 1994, the port law (N. 84) drastically changed the port organisational structure. "Public" ports were replaced by landlord ports in which PAs had the responsibility to coordinate, promote and plan the port activities with a specific prohibition of any direct involvement in port operations. Under this new port model, private stevedoring operators were granted concession agreements giving them the right to have an "operational monopoly" in those areas. 
Consequently, under this model the two main port actors were the PA and the terminal operation company (TOC): while the former one lost its operational powers and gained administrative and planning duties, the latter became the only port actor able to manage a terminal and to handle cargoes. In this organisational model the role of other "minor" players became strategic undertaking port service such as supplying labour pools and marine services.

The results of the 1994 reform were an immediate increase in cargo throughput and massive investments, particularly in the container sector. In the late ' 90 s the port of Gioia Tauro - a new port built on an old industrial site became one of the most competitive transhipment ports in the Mediterranean basin. There were, however, some unresolved issues relating to the PA's limits in its role in port activities and the inability to plan or coordinate any actions beyond the port boundaries.

In the 2000s, problems associated with lengthy delays in decision-making processes by several PAs persisted impacting negatively on investments, particularly relating to the establishment of logistics corridors. This reduced the competitiveness of Italian ports and their catchment areas, especially when compared with other EU competitors such as Koper and Rotterdam. In the last decade, since the mid-2000s, these problems have been underlined by several PA presidents and operators mainly in relation to the stagnation of the Italian port performance in comparison to other Mediterranean ports, particularly the Spanish ports. This was seen as a result of the reduction in new investments and the lack of financial autonomy of the PAs. This restriction slowed investments in the biggest ports in favour of a system of centrally redistributed funds among all the ports. These two problems led to a reduction in the quality of the ancillary and marine services (e.g. Costa and Casagrande, 2011) and drove many shipping companies to other EU competitors, such as Koper.

In order to solve these critical issues - raised by Assoporti, terminal operators and port users - several port reform bills have been discussed in the Italian parliament from the mid2000s onwards but, to date, none have been approved and no action has been implemented to reverse this trend. Ferrari et al. (2015) note that in September 2014 the Government organized a working-group and invited public debate scheduled for early 2015 in order to propose a new reform bill to be enacted by the middle of 2015. No official document has been elaborated at present although rumours suggest a restructure into an aggregation of PAs into regional authorities with the responsibility for planning not only port activities but of the entire logistics corridors.

\section{Country differences and similarities: some key issues}

This paper set out to examine how three countries in different jurisdictions generally serving different trades but, faced with similar problems, implemented some significantly different solutions. Arguably this phenomenon is not explicable in terms of economic theory nor does it always meet the commercial criterion test and has led us to examine policy and decision-making as an inherently part of the political process. Policies do not evolve in a vacuum; or as a tabula rasa. Economic activity, Krugman (2009) argues 'inevitably takes place in a political context' and any thorough research demands an understanding of the political context. The fact that port 'efficiency' may be impacted upon or, indeed, determined by government and political processes are generally ignored. Furthermore, economic theories for much of this time have remained relatively static and have failed to keep pace with paradigmatic changes in port models from a public utility to a statutory authority and now to a commercially oriented market driven one. 
Similarly, quantitative analyses persist and when these methodological approaches fail to address 'real world' issues, and the process becomes too complex there is the tendency, as Joan Robinson argued as far back as the 1930s, to retreat into the thickets of algebra - and in so doing much diminishing the explanatory power required for understanding real world complexities (Robinson, 2015). In other words there is a failure by the majority of researchers to understand or incorporate the significance of the policy process itself.

In this final section, we question how different jurisdictions facing similar problems arrive at different outcomes. Undoubtedly, a number of common issues were identified in all three jurisdictions - governments, along with much of the industrialised world adopted, to a greater or lesser extent, a market oriented approach consistent with the reform trends at the time. They sought, inter alia, to reduce/eliminate inefficiencies in the labour market; reduce the financial burden on governments and set in place ports as landlords; seek investment from the private sector and adopt a policy direction in which ports became integrated into end-toend supply chains.

\section{Reform - successful or not? And on what basis?}

Given this diversity has reform been successful? There is no doubt that in terms of labour market and port efficiency reform has met objectives. In addition, it has distanced government from day to day interference in port operations - an issue that was widely recognised as a major cause of port inefficiency in Australia. It has also deregulated the labour market removing the monopoly control of trade unions. The level of independence ports now have from government varies significantly, however. The Italian case study indicates that ports do not have financial autonomy - an essential element for independence from government and certainly for the effective operation of a market oriented business. But government input into port performance does vary between jurisdictions. In Australia, on the one hand, terminal operators have been distanced from government dictates although lease agreements stipulate future projections and terminal and other charges levied must be approved by the relevant state government regulators. In Brazil, the 1993 port reform, in order to deal with the labour issue, created an entity (the OGMO) that replaced dockers unions in their traditional activities of organizing work shifts and nowadays is also responsible for training programs regarding new port equipment and operational skills required as prescribed by the Convention N. 137 of the International Labour Organization (ILO) in its Recommendation N. 145 from June of 1973. (Brazilian Congress, 1993). As far as investments are concerned, the PAs in Brazil still depend on federal government resources for the public ports. Overall, private sector investments prevail, as new investments are prompted as soon as the new legislation becomes effective.

The landlord port model has been introduced in all jurisdictions and the question must be raised as to the effectiveness of this restructure. In so far as reducing the financial burden on governments, an original objective of reform as discussed above, it has been successful. In effect, however, it has transformed ports from public sector to private sector landlords although government instrumentalities in most cases retain responsibility for essential port functions such as security, channels and environmental protection.

Investment from private sector sources has been an essential part of port reform and in all jurisdictions reform has led to increased private sector investment. Some differences in investment policy are noted however. In Australia, for example, investment in ports came initially from the domestic operators although recently overseas mining companies seeking to form end-to-end integrated chains and secure a source of supply have invested heavily in the 
mining sector, in ports and associated infrastructure. Overseas investment banks and superannuation funds, seeking the safe haven in a relatively thriving economy, have also invested heavily in Australian ports.

Similarly, reform in Italy attracted private sector investments initially mainly from domestic sources (as Contship and Costa Crociere, before its acquisition by Carnival) and was followed by foreign investments such as PSA and APMT as terminal operators. Only recently has the port sector attracted the interest of investment banks (e.g. the project for the Venice new cruise terminal). In Brazil, as in the other jurisdictions, the source of investment has also changed from domestic groups to be followed by foreign investors in partnership with some of the world's largest container carriers (such as MSC and Maersk investment in the Port of Santos (SP); Hamburg Süd investment in Port of Itapoa (SC) or global terminal operators (such as DP World in Port of Santos).

An interesting development has been the emergence of significant changes in the market structure of port operations and the move to monopoly control in some jurisdictions. This is an issue often seen to be contrary to the fundamental objectives of microeconomic reform that focused on efficiency improvements by the introduction of competition. In Italy, for example, reform has incorporated concession agreements authorizing recipients to operate as an "operational monopoly". This is not particularly problematic for container port services as two or more stevedoring companies operate in the largest ports. This has led to significant private sector investment creating a competitive position to the extent that by the late 1990s the Port of Gioia Tauro had become the most competitive transshipment port in the Mediterranean basin. The issue of "operational monopoly" is counterbalanced by prohibiting concessionaires to sign more than one concession contract awarded by the same port authority. Furthermore, the compulsory publicity of port tariffs is likely to safeguard against any abuse of the monopolistic position.

In Brazil, TUPs are linked to integrated supply chains, as they were originally designed to attend to specific demand of dry and liquid bulk cargoes. In addition, there are TUPs operating containers in the Port of Santos (Embraport), which is located in the PP area and outside the organized port area (Portonave) in Port of Itajai and the Port of Itapoa. However, further issues are outstanding, such as OGMO's labour mandatory use and the concession/renting bidding process.

The question of jurisdiction: who does what? A significant difference in the three case studies relates to jurisdiction. On the one hand, multi-jurisdictional control exists in Brazil where federal, state and municipal governments have responsibility for ports while in Italy ports are the responsibility of the central government. In Australia, on the other hand, ports are the jurisdiction of state and territory governments although the federal government has sought greater share in port and infrastructure planning for much of the period following federation in 1901. A major question to be addressed is whether the diversity in jurisdictional control is likely to result in conflicts of interest or funding inequity?

The Italian case study indicates that the PAs have little financial autonomy and decision making among a number of policy and decision-makers has led to lengthy delays in policy formulation causing delays and/or stagnation in investment in new infrastructure. While at the national level, conflict and delays are evident as well as competition between different port communities requesting and competing for funds. This problem is demonstrable by the delays and a committee has been established to resolve this incorporating all the port players. A consensus approach has been adopted and policy proposed by the PA 
must have agreement of all players. In addition, the system in place of centrally distributed funding has led to inequity and a slowing down in investment in the major ports in favor of smaller regional ports and has led to a loss of market share as shipping companies have diverted their business to other competing ports. This is primarily associated with the lack of prioritization at the central government level with regard to funding as all the ports independent of their performance or size - might ask for similar amount of central funds without consideration of the impact on the Italian economy, on the port or the potential of attracting new cargo.

In Brazil, the federal government, as stipulated in the Constitution, is responsible for the port sector although there are a number of bureaucratic bodies involved in the policy process resulting in lengthy delays for effective policy formulation and implementation. In fact, some ports are managed by the Dock Companies under the Federal Government direct control; others by delegation are controlled by the State governments (as Paranagua-PR and Itaqui-MA) while others still are under municipality control (Itajai-SC). All ports, however, irrespective of jurisdiction, are dependent on federal funding for essential infrastructure - for dredging projects, for example.

While there has been significant investment in Brazil's terminals this has occurred under lease agreements many of which are either due to expire and awaiting renewal while in other cases new investors have been sought. The delay in the renewal of concession contracts is a critical issue for some Brazilian ports at present and has led to the slowing down of further investment. It is difficult to know precisely when the present legislation will be enacted and when new concession or renting biddings are likely to occur. This could be related to a conflict between government departments or a political dispute involving vested interested. In effect and as a result, the bidding process has been paralyzed in the Federal Account Audit Court (TCU) since 2013.

State government jurisdiction of Australian ports has been less complicated although the federal government has, since federation in 1901, sought greater input into ports and associated infrastructure. This has been opposed by state and territory governments who have jurisdiction over the country's ports although the federal government does have some input into related areas. Under the Australian Constitution, for example, overseas trade is the responsibility of the federal government and it is not unreasonable, having that responsibility, to ensure that appropriate export infrastructure is in place. To this end, the federal government provides funding to the states and also seeks involvement in port and infrastructure planning - immediate past experience has indicated that this is particularly the case if the Australian Labor Party is in government at the federal level. Since 2013, this pressure has been reduced following the election of a Liberal/National Party coalition government and under a more conservative platform there is a greater tendency to rely on the forces of the market rather than those of the trade unions.

Ports as integrated supply chains: some way to go? it is clear that a common objective of all governments is to link the ports with the landside interfaces forming integrated chains. How effective is this and who is doing this? In Australia some ports, such as the Port of Melbourne Corporation, has the charter to link the port with the landside interface but the port does not have jurisdiction beyond the port precinct. Chain integration has, as a result, been driven in Australia by the private sector - in some cases by 3PLs and in the resources sector it has been driven by the mining companies. 
In Italy there are currently no authorities in charge of supply chains so each private player has to "create" his/her own logistics corridors dealing with a plurality of authorities and other public and private bodies. This situation is a direct result of the legislation that forbids the PA to plan or operate outside the port boundary. The absence of unique and coordinated regulation of logistics corridors - and of supply chains - is embedded in the current legislation which negatively affects competition among Italian and other EU ports (e.g. with the Northern range ports). All recent reform bills - from the middle of 2000s to date - have attempted to deal with this issue. Discussions, indeed, are underway with the prospect of replacing traditional port authorities with regional or logistics authorities.

\section{A final note}

This paper has attempted to contribute to port reform discussions examining and comparing government policy in a number of jurisdictions. The research raised the question why and how governments faced with similar problems implemented significantly different solutions. This outcome was not explicable in terms of economic theory and the paper has argued that there remains a critical need, in port development and efficiency studies, for a much more informed and detailed analysis of the impact of the politics and processes involved.

An important issue for inclusion is not merely what governments choose or choose not to do but on the process of arriving at particular decisions. How and for what reason does an issue emerge on the government agenda? Who and what were the drivers? Who were the winners and losers? This issue is routinely incorporated in political science and political economy disciplines but is neglected, with serious consequences, in mainstream port development and strategy literature frequently leading to simplistic or incorrect conclusions. We believe that our original research question on how governments faced with similar problems implemented significantly different solutions was supported with the selected case studies.

The case studies illustrate that the three jurisdictions, faced with similar problems, implemented what at times have been distinctly different policies - arguably not explicable in terms of economic theory. In other instances, similar outcomes are evident - the landlord model was extensively adopted, with the government acting as regulator and planner. This model has led to profound results - the growing investment of private sector funds in what was traditionally the responsibility of governments. The deregulation of the port sector, in addition, together with the private sector investment has been the enabler of integrated supply chains. Indeed deregulation was a prerequisite for reform for it is well-nigh impossible to integrate supply chains that have, in the past, been essentially the exclusive responsibility of governments.

International trade, globalisation of production and consumption will continue to have a profound impact on ports. This dynamic situation is never static and, arguably, change over the last three decades or so has surpassed that implemented during the preceding century. Future research into further port reform will be commensurate with change.

\section{REFERENCES}


ABTP (2014). Propostas para o setor portuário. Evolução na Legislação e Regulamentação do Sistema Portuário Brasileiro, Agosto de 2014. Available at http://www.abtp.com.br/downloads/propostas-da-abtp-para-setor-portuario.pdf

ABARE (2010). Australian Commodities Statistics 2010. Australian Bureau of Agriculture and Resource Economics. Available at http://www.agriculture.gov.au

AGPS (2010). Australian Commodities Statistics. Australian Bureau of Agriculture and Resource Economics, AGPS Canberra.

ANTAQ (2015). Agência Nacional de Transportes Aquaviários. Available at http://www.antaq.gov.br/Portal/.

ANTAQ (2014). Agência Nacional de Transportes Aquaviários. Statistical Yearbook 2013. Available at http://www.antaq.gov.br/anuario/.

ASSOPORTI (2014). Italian Seaports Association statistics. Available at www.assoporti.it.

ALC (2008). The National Strategy for the Transport and Logistics and Freight Industry: Enhancing Australia's Supply Chains. (Barton: Australian Logistics Council).

Australian Constitution (1901). Commonwealth of Australia Constitution Act S51.

Baird, A. J., Valentine, V. F. (2007). Port privatisation in the United Kingdom. Research in Transportation Economics, 17, 55-84, Elsevier.

Beresford, Q. (2000). Governments, markets and globalisation. St Leonards, NSW: Allen \& Unwin.

Brazilian Congress (1993). Congress Decree N. 29, approving terms of the Convention N. 137 and Recommendation N. 145 of $58^{\text {th }}$ Session of International Labour Organization (ILO), Geneve, 25 June 1973. Avaliable at http://www2.camara.leg.br/legin/fed/decleg/1993/decretolegislativo-29-22-dezembro1993-358293-publicacaooriginal-1-pl.html.

Brooks, M. \& Culliname, K. (2007). Devolution, Port Governance and Port Performance. Research in Transportation Economics, 17, Elsevier.

Business Spectator (2014). Digging beneath China's interest in Australian iron ore projects. $\quad$ Retrieved from http://www.businessspectator.com.au/article/2014/5/14/china/digging-beneath-chinasinterest-australian-iron-ore-projects on May 14 ${ }^{\text {th }}, 2014$.

Cariou, P., Dagnet, F. \& Fedi, L. (2014). The new governance structure of French seaports: an initial post-evaluation. Maritime Policy \& Management, 41(5), 430-443. 
Chalmers, A.F. (1999). What is this thing called science? Brisbane: University of Queensland Press.

Chen, S. L. \& Everett, S. (2014). The dynamics of port reform: different contexts similar strategies. Maritime Policy and Management, 41(3), 288-301.

Costa, P. \& Casagrande, M. (2011). Dalla concorrenza nei porti alla concorrenza tra $i$ porti. Il Caso dei Servizi Tecnico-Nautici in Italia. Venezia: Marsilio editori.

Cullinane, K.; Wei, Y. Y. \& Lam, J. (2007). The port of Singapore and its governance structures. Research in Transportation Economics, 17, 285-310, Elsevier.

Dotars (2002). Freight Logistics in Australia - An Agenda for Action. Canberra, AU: Department of Transport and Regional Services, Australian Government.

Dotars (2004). AusLink White Paper. Canberra, AU: Department of Transport and Regional Services, Australian Government.

Everett, S. \& Pettitt, T. (2006). Effective corporatisation of ports is a function of effective legislation: Legal issues in the existing paradigm. Maritime Policy and Management 33(3), 219-232.

Everett, S. \& Robinson, R. (2007). Port Reform: The Australian Experience. Research in Transportation Economics, 17, 259-284, Elsevier.

Everett, S. \& Robinson, R. (2012). Value innovation: new entrants and chain restructuring in Australia's export coal chains. Journal of International Logistics and Trade, 10(3), 3-17.

Fawcet, J. A. (2007). Port governance and privatisation in the United States: Public ownership and private operation. Research in Transportation Economics, 17, 207-235, Elsevier.

Ferrari, C., Tei, A., \& Merk, O. (2015). The Governance and Regulation of Ports - The Case of Italy, ITF/OECD Discussion Paper nr. 1, Paris.

Galvão, C. B., Robles, L. T. \& Guerise, L. C. (2013). The Brazilian seaport system: A post-1990 institutional and economic review. Research in Transportation Business \& Management, 8, 17-29.

Goss, R. O. (1990). Economic policies and seaports: strategies for port authorities. Maritime Policy and Management, 17(4), 273-287.

Goss, R.O. (1997). British Ports Policies since 1945. Journal of Transport Economics and Policy 32(1), 51-71.

Government of Western Australia Department of Mines and Petroleum (2013). Annual Report 2013. Available at www.dmp.wa.gov.au/ 
Infrastructure Australia (2010). Developing a national freight network strategy: Perspectives of freight network customers. The Allen Consulting Group. May, Canberra. Available at http://infrastructureaustralia.gov.au/policypublications/publications/files/freight_network_customer_perspectives.pdf

Infrastructure Australia and NTC (2010). National ports strategy: Background paper 2010, Canberra. Available at http://infrastructureaustralia.gov.au/policypublications/publications/files/ports_strategy_background_paper_20_December_2010.p df

King, S. \& Maddock, R. (1996). Unlocking the infrastructure: The reform of public utilities in Australia. (Sydney: Allen and Unwin).

Krugman, P. (2009). End this depression now. New York: WW Norton \& Co USA.

Kuhn, T. (1970). The Structure of Scientific Revolutions. Chicago: University of Chicago Press.

Macfarlane, I. (2006). The search for stability. Sydney: ABC Books.

Madison, A. (1991). Dynamic forces in capitalist development: A long-run comparative view. Oxford, UK: Oxford University Press Oxford.

National Competition Policy (199)5. Commonwealth of Australia Commonwealth Competition Policy Reform Act 1995.

Newcastle Port Corporation (2013). Annual Report 2013. Available at http://www.newportcorp.com.au/site/index.cfm?display $=327004$

Parola, F., Tei, A. \& Ferrari, C. (2012). Managing Port Concessions: Evidence From Italy', Maritime Policy And Management, 39 (1), 45-61.

Ports Of Australia (2015). Australian port map location. Available at http://www.portsaustralia.com.au/

Quiggin, J. (1996). Great Expectations: Microeconomic reform in Australia. Sydney: Allen and Unwin.

Reuters. (2014). POSCO backs rail, port plan for Baosteel Australian iron ore project. Retrieved from http://www.reuters.com/article/2014/09/11/us-australia-iron-aurizonidUSKBN0H60XB20140911 on September $11^{\text {th }}, 2014$.

Righetti, G. (1987). Trattato di Diritto Marittimo. Milan: Giuffré Editors.

Robinson, J. (1932). Economics is a serious subject: The apologia of an economist to the mathematician, the scientist and the plain man. W. Heffer \& Sons. 
Robinson, R. (2002). Ports as elements in value-driven chain systems: the new paradigm, Maritime Policy and Management, 29(3), 241-255.

Robinson, R. (2009). Chain systems analysis: new thinking about supply chain efficiency. Monograph in Chain Systems Analysis, Centre for Integrated Freight Systems Management, University of Melbourne.

Robinson, R. (2015). Cooperative strategies in port-oriented bulk supply chains: aligning concept and practice. Journal International Journal of Logistics Research and Applications, 18, 193-206.

Skidelsky, R. (2010). Keynes, the return of the master. New York: Penguin

Wang, J. J.; Ng, A. \& Olivier, D. (2004). Port Governance in China: A review of policies in an internationalizing port management practices. Transport Policy, 11, 237250 .

World Bank (2001). Port Reform Tool kit. Washington, DC: Transport Division.

Yin, R. K. (2003). Case Study Research - Design and Methods. Third edition. London: Sage. 